„Kwartalnik Filmowy” nr 111 (2020)

ISSN: 0452-9502 (Print) ISSN: 2719-2725 (Online)

https://doi.org/10.36744/kf.397

(c) Creative Commons BY-NG-ND 4.0

Barbara Szczekała

badaczka niezależna

https://orcid.org/oooo-0001-9576-9629

\title{
Odczuwanie obcości. Afektywność wspólezesnego science fiction
}

\author{
Slowa kluczowe: \\ afekt; \\ melodramat; \\ kobiecość; \\ science fiction; \\ ucieleśnienie; \\ empatia
}

\begin{abstract}
Abstrakt
Artykuł jest afektywną analizą współczesnych filmów science fiction z perspektywy specyfiki kobiecego doświadczenia. Cechą charakterystyczną najnowszych produkcji fantastycznonaukowych jest afektywno-emocjonalny kontakt z pozaziemską obcością. Doświadczenie to jest ucieleśniane także przez widzów. Mimo ikonografii oraz prób popularyzacji nauki właściwych temu gatunkowi trybem narracyjnym omawianych filmów (m.in. Anihilacji, Interstellara i Nowego poczatku) jest melodramat, w którym bohaterki poznaja i działają nie tylko dzięki wiedzy i rozumowaniu, lecz także przez emocje i afekty. W artykule są analizowane następujące aspekty filmów science fiction ostatniej dekady: cielesne doświadczanie obcości, afektywne sprzężenia między obcym a swoim, alternatywne doświadczanie czasu mediowanego niestandardową narracją, fokalizacja i kinodynamika kosmicznych spektakli oraz afektywne doświadczenia odbiorcze (ucieleśnienie, empatia oraz identyfikacja).
\end{abstract}


Kino science fiction afektuje obcość i jest obcością zaafektowane ${ }^{1}$. Coraz odważniej rezygnuje z racjonalnej kolonizacji tego, co nieludzkie i nieziemskie, oddając pierwszeństwo odczuciu, przyswojeniu, intuicji i empatycznemu doświadczeniu kosmicznej inności. W ostatnich latach pośredniczkami tego typu przeżyć najczęściej są bohaterki. Naturalną konsekwencją feminizacji filmowej fantastyki naukowej wydaje się jej melodramatyzacja, dzięki której uczuciowość i doznaniowość to sposoby poznania równie ważne, jak racjonalność i naukowość. Co więcej - afektywność filmów science fiction wpływa nie tylko na profilowanie ekspresji bohaterów filmowych, lecz także na doświadczenie odbiorcze wpisane w relację film - widz $z^{2}$.

\section{Obcość - niezwykłość}

Afektywność kina science fiction chciałabym opisać na podstawie filmów ostatniej dekady. Choć elementy melodramatyzacji, doznaniowość i akcentowanie intuicyjnego czucia kosmicznej inności są obecne w tym gatunku od dawna, to jednak zyskały na sile dzięki feminizacji fantastyki naukowej postępującej w XXI w. Feminizacja i melodramatyzacja filmów science fiction ostatnich lat jest na tyle wyraźnym zjawiskiem, że zdaje się łączyć rozproszone i „niekanoniczne” nurty oraz podgatunki mieszczące się pod parasolowym terminem „fantastyki naukowej”. Dostrzeżemy je w wizjonerskich superprodukcjach pokroju Interstellar (reż. Christopher Nolan, 2014) i Grawitacji (Gravity, reż. Alfonso Cuarón, 2013), intelektualnie stymulujących filmach Alexa Garlanda (Ex Machina z 2015 r. i Anihilacja /Annihilation/ z 2018 r.), w Nowym początku (Arrival, 2016) Denisa Villeneuve'a, w kinie superbohaterskim (Kapitan Marvel /Captain Marvel/, reż. Anna Boden, Ryan Fleck, 2019), „dramatach astronautycznych" (Pierwszy człowiek/First Man/, reż. Damien Chazelle, 2019; Ad Astra, reż. James Gray, 2019; Lucy in the Sky, reż. Noah Hawley, 2019; Proxima, reż. Alice Winocour, 2019), a także w europejskim art-housie (High life, reż. Claire Denis, 2019). Podobną tendencję zobaczymy też we współczesnym serialu - w Westworld (HBO, 2016 -), Devs (HBO, 2020) czy Star Trek: Discovery (CBS, 2017 -). Ekspansja fantastycznonaukowego afektu jest na tyle bezwzględna, że nie oszczędziła nawet współczesnych ikon męskości, pozwalając Bradowi Pittowi, Ryanowi Goslingowi, Matthew McConaugheyowi i Nickowi Offermanowi na kosmiczną lub fantastycznonaukową przygodę pod warunkiem ujęcia jej w tryby melodramatu ojcowskiego.

Zaafektowanie dziwnością i „dziwna afektywność”, odczuwanie kosmicznej obcości czy też przyswajanie pozaziemskiej inności będą zatem wspólnym mianownikiem wewnątrzgatunkowych nieścisłości, hybryd i odstępstw - dotyczą wszakże zarówno widowisk paranaukowych, „realistycznych” filmów o podróżach kosmicznych, (para)biografii astronautów, filmów o podróżach w czasie, soft science fiction jak i superbohaterskich space operas. We kinie głównego nurtu posługującym się ikonografią kosmiczną (statki, skafandry astronautów, dryfowanie bohaterów w stanie nieważkości, wizualizacja wszechświata, nieskończoności, itd.) lub eksplorującym technologiczną przyszłość (sztuczna inteligencja, futurystyczna technika, technofobia, technofilia i technokracja) zasadniczą rolę odgrywa nie tyle racjonalne i naukowe poznanie tego, co obce, pozaziemskie i niepojęte, ile jego afektywno-empatyczne odczuwanie ${ }^{3}$. 
Fenomen fantastycznonaukowej afektywności i melodramatyzacji science fiction jest - paradoksalnie - „naturalny” dla kina sc-fi z jeszcze jednego powodu - wydaje się wariacją „poznawczego uniezwyklenia”, które w kanonicznej koncepcji Darko Suvina jest dystynktywną cechą narracji fantastycznonaukowych. Science fiction byłoby zatem takim gatunkiem literackim, za którego konieczne i swoiste wykładniki uznać należałoby obecność i wzajemne powiazanie wyobcowania oraz poznania, towarzyszacych wytwarzaniu alternatywnego pola odniesienia względem empirycznego środowiska autora ${ }^{4}$ - zakładał Suvin, odwołując się do formalistycznej idei chwytu uniezwyklającego autorstwa Wiktora Szkłowskiego. Według Szkłowskiego „uniezwyklenie” (tłumaczone także jako „udziwnienie” lub „wyobcowanie”) to immanentna właściwość sztuki (w szczególności poezji), polegająca na jej niecodziennej i nieprzeźroczystej formie, której celem jest wyzwalanie rzeczy z automatyzmu percepcji ${ }^{5}$. Owo odbiorcze wyzwolenie ma skłaniać do świadomego i nietransparentnego odbioru dzieł. W ślad za tym przekonaniem Suvin twierdzi, że najciekawsza literatura fantastycznonaukowa powinna być przede wszystkim stymulująca intelektualnie, zarówno jeśli chodzi o jej powinowactwa z nauka, jak i filozoficzno-społeczny komentarz do współczesności. Źródłem tego pobudzenia myślowego ma być uniezwyklenie poznawcze ulokowane w tekstualnej warstwie fantastycznonaukowych fikcji: w konstrukcji bohaterów, światotwórstwie, alternatywnej czasowości czy narratywizacji tzw. hard science. Konieczne jest - przekonuje Suvin - zapotrzebowanie science fiction na wyższe zaplecze poznawcze niż to zwykle wymagane od przeciętnego czytelnika - gotowość na wyobcowujace novum składa się bowiem na raison d'être gatunku ${ }^{6}$. Opuszczając zasłonę milczenia na elitarystyczne wartościowanie Suvina, warto przyjrzeć się poznawczemu komponentowi jego obserwacji. Z perspektywy najnowszych filmów science fiction kluczowy wydaje się bowiem postulat gotowości na wyobcowujące novum. Doświadczanie dziwności, inności i niezwykłości zawsze było jednym z wiodących motywów fantastyki naukowej. W odsłonie współczesnej i melodramatycznej ta epistemologia urasta do rangi tematu najważniejszego, niemal ostatecznego. Jak poznać obcość, która - radykalnie odmienna od tego, co znane - wymyka się oswojeniu? Jak koegzystować z kosmiczną innościa, która intryguje niesamowitością, ale też niesie potencjalne zagrożenie? Czy można ująć nowe doświadczenia w ramy znanego skryptu (językowego, doświadczeniowego, naukowego), jednocześnie ich nie zawłaszczając? Oto pytania, które za pośrednictwem filmowych bohaterek coraz częściej zadaje kino. Do odpowiedzi na nie wiodą rozmaite afekty oraz doznania, odczucia, intuicje, przebłyski i empatia.

Tezę Suvina, że science fiction jako gatunek akcentuje wyjątkowy (uniezwyklony czy wyobcowujący) tryb poznania, rozwija - także na gruncie literaturoznawczym - Ritch Calvin, przekonując, że fantastyka naukowa pisana przez kobiety konfrontuje i kwestionuje tryby ptci i gatunku. W tym celu to, co nazywam "feministycznym epistemologicznym science fiction" [feminist epistemological science fiction], porusza zagadnienia wiedzy $i$ jej produkcji jako środków do rozpracowania i podważania konwencji gatunkowych ${ }^{7}$, co więcej - [niektóre] feministyczno-naturalistyczne epistemologie wartościuja materialne ponad niematerialne, cielesne (corporeal) ponad umystowe i powszednie ponad idealne ${ }^{8}$. Choć wymienione wyżej filmy w mniejszości są reżyserowane przez kobiety, charakteryzują się pewną kobiecą doświadczeniowością w mediowaniu której zasadniczą rolę odgrywają afekty. Lena 
(Natalie Portman) w Anihilacji nie tyle walczy z obcościa, ile jej doznaje i ją przyswaja. Louise (Amy Adams) w Nowym poczatku intuicyjnie i bez uprzedzeń wystawia się na niezwykłe i nowe czaso-odczucie. Amelia (Anne Hathaway) w Interstellar finalnie udowadnia, że intuicja znaczy więcej niż obiektywna analiza danych. Sarah (Eva Green) w Proximie zestraja pragnienie podróży kosmicznej i wyzwanie macierzyństwa. Maeve (Thandie Newton) z Westworld i Lily (Sonoya Mizuno) z Devs ufają własnej intuicji, która wygrywa z gaslightingiem i manipulacją technologiczną. W Star Trek: Discovery to przeczucie i migotliwe wspomnienia każą Michael (Sonequa Martin-Green) śmiało kroczyć tam, gdzie nie dotarł jeszcze żaden człowiek.

Afekt jest cennym sposobem poznania w science fiction. Obcość coraz rzadziej jest w nim kolonizowana czy okiełznana, częściej - alternatywnie doświadczana i przeżywana. Także przez widzów empatyzujących z filmowymi bohaterkami.

\section{Afektywność - dziwność}

Czym jest afekt we współczesnym science fiction? Opisując ten fenomen, warto pamiętać, że dotyczy zarówno relacji bohaterów ze światem przedstawionym, jak i doświadczania filmu przez widzów. W kinie tego gatunku, w dramatach astronautycznych czy filmach futurystycznych sprzężenie między cielesnym i umysłowym, doznaniowym i intelektualnym, afektywnym i rozumowym oraz intuicyjnym i intelektualnym będzie kluczowym wymiarem doświadczania obcości zarówno w przypadku bohaterek filmowych, jak i widzów. Afekt będzie zatem ekranowy (zaafektowane są filmowe protagonistki), jak i kinowy (filmowa obcość afektuje także doświadczenia odbiorcze).

W obu przypadkach afekt będzie zawsze związany z emocjami i poznaniem. Dynamikę cyrkulacji wszystkich tych wymiarów w doświadczaniu kina współczesnego charakteryzuje Steffen Hven: By lepiej zrozumieć wspótczesna złożoność kina na jej własnych warunkach, należy wskazać nowy tryb odbioru, który rozszerza kinowa percepcje dzięki "ucieleśnieniu” świata opowieści. Wbrew dominujacym badaniom uważam, że złożoność współczesnego kina polega nie tyle na zawitym, mglistym bądź skomplikowanym sjużecie i dramaturgii, ile na "woli złożoności", rozumianej jako podkreślenie wzajemnych zależności kinowych wymiarów, które tradycyjnie były rozdzielane. Z tej perspektywy kino współczesne (...) skłania nas do przemyślenia współzależności w poznawczym, emocjonalnym i afektywnym obiegu, który ustanawia doświadczenie filmowe?.

Ciekawym przykładem ekranowego afektowania obcości jest Anihilacja. Film Alexa Garlanda jest adaptacją książki Unicestwienie Jeffa VanderMeera, która bywa klasyfikowana jako weird fiction - „podgatunek" fantastyki naukowej skupiający się na eksplorowaniu dziwności i niesamowitości oraz powiązanych z nimi lęku i niebezpieczeństwa. Weird, strange i eerie (dziwny, obcy, niepokojący) są słowami znakomicie opisującymi filmową sytuację, padają też z ust skonfundowanych bohaterek próbujących opisać rzeczywistość, w jakiej się znalazły. Film rozpoczyna się, gdy kometokształtna materia uderza w latarnię morską i wytwarza wokół niej Strefę X, w której nie działają tradycyjne prawa fizyki ani biologii. Gdy kilka wojskowych wypraw mających na celu zdiagnozowanie tej obcości i zebranie danych dotyczących pozaziemskiego zjawiska ponosi klęskę, do epicentrum zdarzenia zostają wysłane naukowczynie. Znajduje się wśród nich Lena, główna bo- 
haterka filmu - mikrobiolożka specjalizująca się w badaniu komórek nowotworowych. Wcześniej mąż Leny, sierżant Kane, jako jedyny przeżył ekspedycję do Strefy X. Jego nagły powrót do domu wydaje się kobiecie cokolwiek dziwny, Lena wyczuwa „nieswojość" męża, a jego stupor i konfuzja budzą w bohaterce niepokój. Już pierwszy kontakt z niezidentyfikowaną obcością jest zatem afektywny - wymyka się językowi, paraliżuje i intryguje jednocześnie, nie wpisuje się w znane schematy zachowań, a tym samym - opiera się racjonalizacji. Mimo naukowego kieratu, w jakim żyła bohaterka, od momentu nagłego pojawienia się w domu „nieswojego" Kane'a jej dalszym poczynaniom będą towarzyszyć ambiwalentne i dziwnie rezonujące odczucia. Filmowa doświadczeniowość ${ }^{10}$ będzie odpowiadała paradefinicji afektu zaproponowanej przez Briana Massumiego - intensywności, którą można sklasyfikować jako stan emocjonalny, a ów stan to temporalny i narracyjny szum. To stan zawieszenia, a potencjalnie zerwania. Z perspektywy naszego rozumienia i narracji to jakby temporalny wir, dziura w czasie. Ściśle rzecz biorac, nie jest to stan bierny, wypetnia go bowiem ruch, wibracja i rezonans ${ }^{11}$.

Afekt rozumiany jako trudna do zdefiniowania intensywność, niepokój i drżące pobudzenie wystawiające na nowe doświadczenia i wprawiające w stan gotowości będzie także kierować bohaterkami innych filmów. W dramacie astronautycznym Lucy in the Sky protagonistka nie potrafi zwerbalizować przeżycia podróży kosmicznej, swój leksykalny deficyt kamuflując lapidarnym stwierdzeniem „nie wiem”, jednocześnie przyznając: I've never felt so alive. O swoim locie w kosmos mówi The Experience, absolutyzując owo Doświadczenie jako najważniejsze w życiu. Orbitowanie wydaje się tyleż zdumiewające, ile obezwładniające; Lucy jest tak mocno pochwycona kosmicznym afektem, że za wszelką cenę pragnie kolejnej wyprawy. Niepokój wobec przyszłości podziela bohaterka Proximy - astronautka przygotowująca się do pierwszego lotu w kosmos. Mimo fizycznej, intelektualnej i emocjonalnej gotowości na wyprawę, nie potrafi pogodzić antycypacji tego, co pozaziemskie z codziennością i obowiązkami macierzyńskimi. Nawet W „realistycznych” dramatach astronautycznych doświadczanie obcości będzie przede wszystkim afektywne: związane z gotowością i niepokojem, rozedrganiem i słowną indolencją. Afekt pojawia się pomiędzy, w prześwitach, w pęknięciach, w niedostawaniu do siebie płaszczyzn porozumienia i rozumienia, w nagromadzeniach intensywności, w akumulacji przeżyć, które nie zawsze w petni przyswojone nękaja nasza narrację o nas samych, siedza gdzieś, tkwia w zdjęciach, w dokumentacjach jako widma w archiwach, zapisane, ale nie przyswojone, zarejestrowane, ale nie wywołane ${ }^{12}$ - pisze Katarzyna Bojarska. Afekt zdaje się niewysławialny. Opiera się werbalizacji - a co za tym idzie racjonalizacji - zarówno w dialogach filmowych, próbie słownej ekspresji doświadczenia seansu filmowego, jak i w dyskursie humanistycznym. We wszystkich tych sferach opisywanie afektu wiąże się z użyciem metafory, metonimii lub porównania, quasi-poetyckiego języka, który dotyka istoty rzeczy, ale jej nie ogranicza. Rezerwuar "afektywnych słów” zawiera między innymi: doznanie, drganie, intensywność, namiętność, napięcie, niespodziewane, niewyjaśnione, pobudzenie, poczucie, przeczucie, ruch, rezonans, szum, wir, ulotne. Jak pisze Kinga Siewior, afekt to poza-świadoma, cielesna reakcja na jakiś zewnętrzny impuls. (...) Ich momentalność i fizyczność sprawia, że wymykaja się jakimkolwiek ujęciom językowym, nie tworza spójnego słownika, lecz co najwyżej szum. (...) Chwile po zaistnieniu afekt zostaje rozpoznany jako ekscytacja lub przerażenie, a następnie wtaczony w osobista narracje jako radość, 


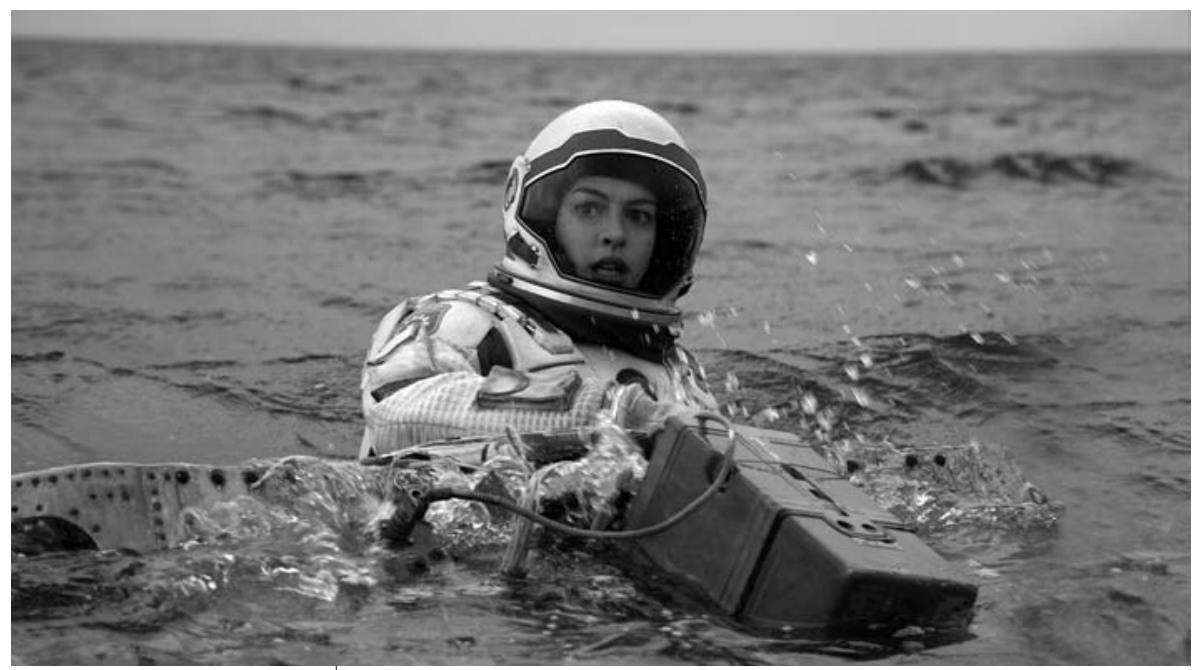

Interstellar, reż. Christopher Nolan (2014)

strach itd. Czasami jednak pozostaje zawieszona w przestrzeni, niedoprecyzowana, bo zbyt trudna lub nieprzystająca do żadnego z wariantów wyuczonego przez jednostke emocjonalnego skryptu dziwnościa ${ }^{13}$. Obcość i dziwność będą zatem zarzewiem afektu, który może - choć nie musi - zostać zidentyfikowany jako emocja i werbalnie okiełznany.

Jeśli zatem afekt wymyka się językowi, czy będzie równie oporny w przypadku filmu? Czy „,ekranizacja” afektu będzie podobnie problematyczna, jak jego werbalizacja? Współczesne kino science fiction stara się sprostać wyzwaniu wizualizacji kosmicznej obcości. Choć nadal wpada w koleiny antropomorfizacji (humanoidalne istoty w Anihilacji i Nowym początku) lub przedstawia obcość jako ruchomy kolorowy bezkształt niczym z psychodelicznej halucynacji, kładzie nacisk nie tyle na samą obcość, ile na jej poznanie i kontakt z nią. Przywoływane tutaj filmy - Anihilację, Nowy początek, Ex Machina, Interstellara - łączą charakterystyczne sceny próby kontaktu przez dotyk, w których bohaterki w geście niepewnego, choć pokojowego porozumienia wyciągają dłoń w kierunku tego, co nieznane. Dotyk i ciało stają się zatem pasem transmisyjnym dla nowego doświadczenia związanego z otwartością i gotowością na nie-swoje doznanie. Gest dotyku nie jest ani zawłaszczający, ani racjonalizujący. Otwierający na bezpośredniość doznania i somatyczne spotkanie wystawia bohaterki na to, co niepojęte, intensywne, inne. W Anihilacji będzie to złowieszczo piękna sceneria lasu ukwieconego roślinami powstałymi w wyniku mutacji genetycznej. W Interstellarze - scena podróży przez tunel czasoprzestrzenny, gdy bohaterka w geście ekscytacji wystawia dłoń, która zostaje chwilowo odkształcona i pofałdowana przez siłę fal grawitacyjnych. W Nowym poczatku pierwszy niezapośredniczony kontakt protagonistki z obcymi polega na wejściu w ich atmosferę, w której otula ją gęsta mleczna mgła, będąca najprawdopodobniej nośnikiem informacji i alternatywnego doznania czasu. W stopniu, w jakim jest to możliwe, współczesne kino science fiction stara się nie tylko przedstawiać kontakt z obcością lecz także owo doświadczenie symulować, poniekąd zachęcając widzów do powtórzenia gestu bohaterek i wyciągnięcia 


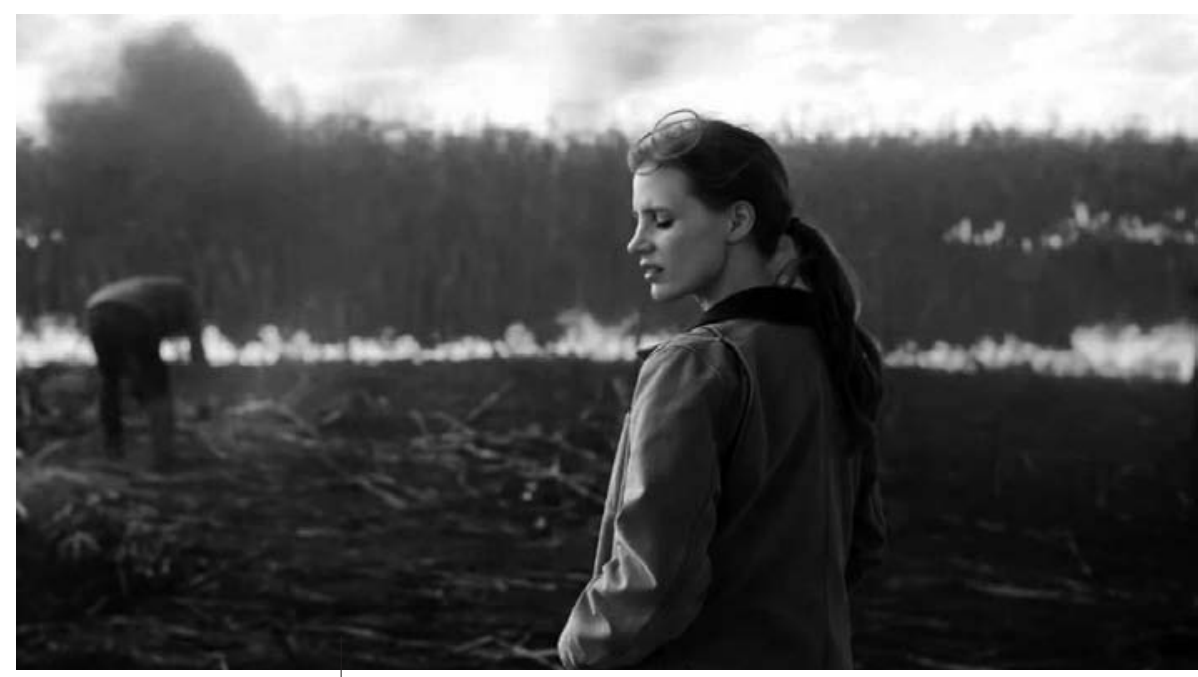

Interstellar, reż. Christopher Nolan (2014)

otwartej dłoni w stronę ekranu. Takie ujęcie tematu przełoży się więc na alternatywne sensorium filmowe, które poza wzrokiem i słuchem będzie stymulować także zmysł dotyku, wytwarzając nęcące zjawiska lub światy przedstawione, których elementy charakteryzują się szczególną haptycznością.

Dotykanie obcości jest sprzężone z byciem dotkniętą obcością. Ta dwustronna relacja okazuje się obopólnym „stawaniem się" - zaafektowanie obcością sprawia, że bohaterki filmowe przejmują jej właściwości i rezonują jej intensywnością; obcość z kolei także chyba absorbuje ich indywidualność - kształty i ruchy. Zupełnie jak w koncepcji Gilles'a Deleuze'a i Féliksa Guattariego, według których zmystowe stawanie się jest aktem, poprzez który coś lub ktoś stale staje-się innym (będąc nadal tym, czym jest $)^{14}$. Zgodnie $\mathrm{z}$ tym podejściem afekt jest rodzajem korporalnego i sensorycznego pobudzenia, podczas którego stajemy się gotowi do bliżej nieokreślonego działania. Jest przed-intelektualny (wyprzedza proces myślenia), momentalny i doznaniowy. Co więcej, afekt ewokuje pewien alternatywny stan, umożliwia wymianę polegającą na tym, że człowiek doznający afektu może na chwilę stać się jego źródłem. Afekt nie jest przejściem od jednego stanu przeżytego do innego, lecz nieludzkim stawaniem się człowiek ${ }^{15}$ - dodają filozofowie. W kinie science fiction to nieludzkie stawanie się będzie opisywanym wyżej zaafektowaniem obcością - nie tyle jednak oswojeniem jej, ile zaabsorbowaniem jej cech bądź elementów. Obcość zawsze będzie zatem istniała w kontakcie z tym, co znane; „swoje” będzie kontekstem dla „innego" i vice versa, a owo obopólne „stawanie się" ma naturę afektywną - jest doznaniowe, przedjęzykowe, kontaktowe i niepokojące.

Znakomicie obrazuje to Anihilacja, do wątku kontaktu z obcością dodając motyw samozniszczenia. Każda z uczestniczek wyprawy do Strefy X (zwanej Iskrzeniem) zmaga się z jakimś rodzajem autodestrukcji: nieprzepracowaną traumą po śmierci najbliższej osoby, nałogiem, nowotworem, próbami samobójczymi albo wyrzutami sumienia po zdradzie męża. Może się wydawać, że członkinie ekspedycji nie mają nic do stracenia, są więc idealnymi kandydatkami do misji skazanej na niepowodzenie. Okazuje się jednak, że Iskrzenie wpływa na każdą z nich w nieco inny 


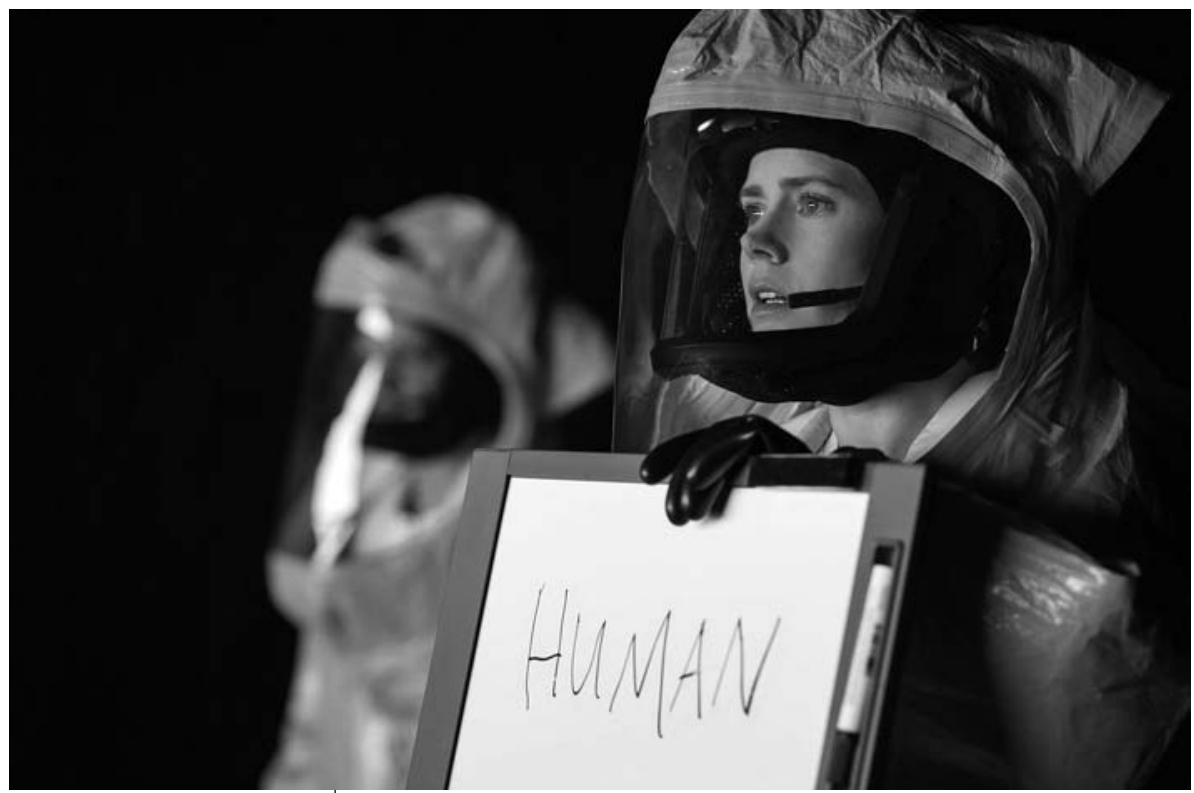

Nowy poczatek, reż. Denis Villeneuve (2016)

sposób, trudny do jednoznacznego sklasyfikowania jako negatywny albo pozytywny, opisywany raz jako dezintegracja i rozpad, raz jako coś „niebywale pięknego". Proces refrakcji zachodzący w obrębie pozaziemskiego zjawiska wywołuje rozliczne "dziwne" mutacje polegające na tworzeniu duplikatów organizmów lub mieszaniu różnych gatunków. Ich przejawem jest aligator o uzębieniu rekina, różne gatunki kwiatów wyrastające z tej samej łodygi, skupiska flory o ludzkich kształtach, niedźwiedź, z którego wydobywają się przedśmiertne jęki ludzkiej ofiary, w końcu - ludzie, z których ciał kiełkują rośliny i pączkują kwiaty. Choć początkowo bohaterki starają się zracjonalizować Iskrzenie i wytłumaczyć je tym, co znane (prawami fizyki, biologii, języka), szybko zdają sobie sprawę z faktu, że niezidentyfikowana obcość jest częścią ich samych, a podział na „,swoje” i „zewnętrzne” przestaje istnieć; to jest we mnie - powie jedna $\mathrm{z}$ nich. Kulminacją owego procesu jest scena finałowa, w której protagonistka zostaje skonfrontowana z obcością przejmującą jej kształty, kopiującą ruchy i naśladującą zachowania. Niepokojąca i niejednoznaczna scena mimetycznego tańca, w którym metaliczny humanoid zmierza do przybrania postaci Leny, kończy się radykalną decyzją bohaterki, która umieszcza w dłoni swojej nowo wytworzonej sobowtórki granat - jego wybuch prowadzi do zniszczenia zarówno kopii kobiety, jak i całej Strefy. Ta anihilacja wydaje się zatem pokłosiem autodestrukcji bohaterki niebojącej się unicestwić samej siebie. Jak się jednak okazuje w enigmatycznym, otwartym zakończeniu, Iskrzenie nie zostało całkowicie pokonane. Rezonuje i drga w zbliżających się do siebie Lenie i jej mężu, spowija ich niczym hiperobiekt, opalizuje w ich oczach.

Afektywność jako dominanta doświadczeniowa science fiction tylko pozornie powinna zaskakiwać. W rzeczywistości jest bowiem naturalnym stanem poznawania i doznawania obcości. Nie dziwi zatem, że kino futurystyczne lub fantastycznonaukowe korzysta z dramaturgicznego lub ikonograficznego repertuaru gatunków, 


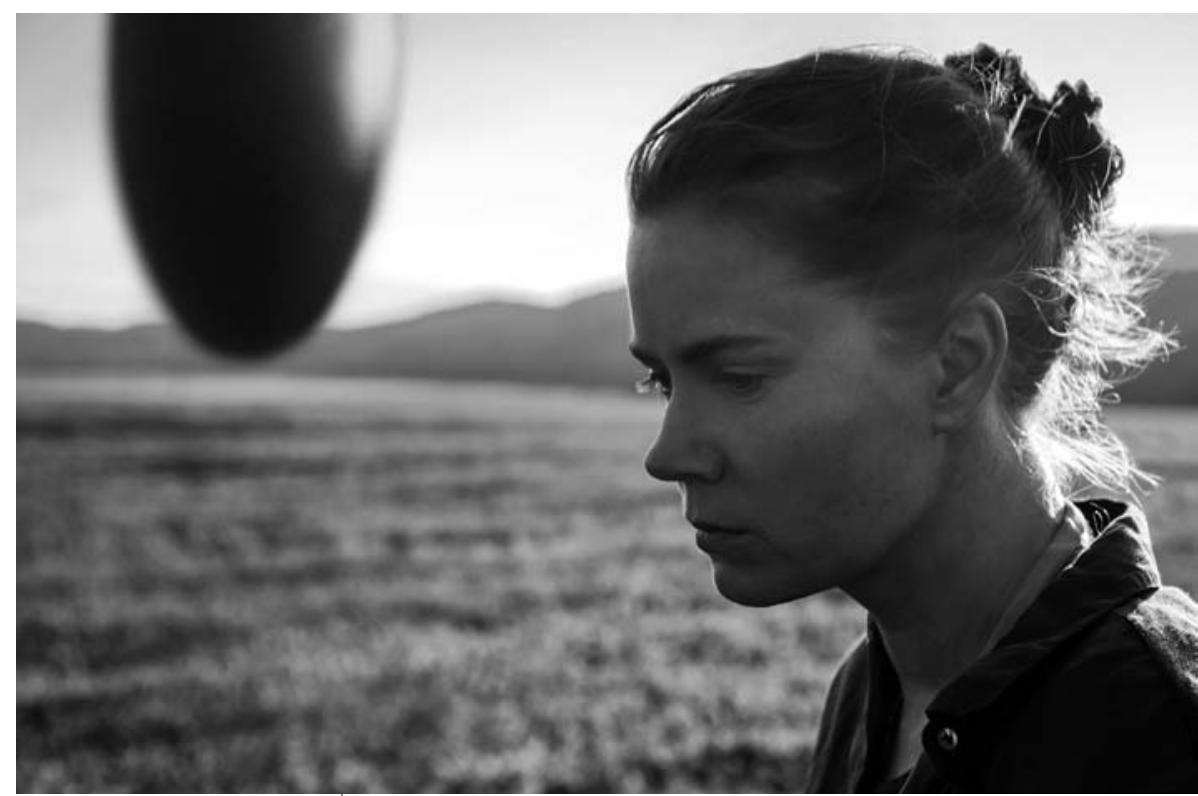

Nowy poczatek, reż. Denis Villeneuve (2016)

które Linda Williams określiła jako cielesne - horroru oraz melodramatu ${ }^{16}$. Bohaterki przywołanych filmów są połączone podobnym przeżywaniem tego, co obce, inne i pozaziemskie. W owych doznaniach ważną rolę odgrywa ciało i intuicja, niezwykle istotne w percypowaniu nie tylko przestrzeni, lecz także czasu.

\section{Kolistość - czasowość}

Czas w kinie science fiction bywa nielinearny i niemierzalny. Doświadczenie czasowości jest jednym z głównych tematów kina fantastycznonaukowego, a mediujące je bohaterki często są zaafektowane „dziwnym” czaso-odczuciem, zgoła odmiennym od tego, które wyznacza kalendarz i rytm wskazówek zegara. Alternatywne trajektorie czasu filmowego są sprzężone $\mathrm{z}$ nielinearną lub niechronologiczną strukturą narracyjna, w której modyfikacji podlega zwłaszcza relacja przyczyny i skutku. Najwyraźniej widać to w produkcjach spod znaku mindgame films: Interstellarze, Nowym poczatku, Westworld i Devs, których struktura opowiadania przypomina pętlę lub koło. Bardziej subtelne, choć nadal niestandardowe doznanie czasu charakteryzuje natomiast Anihilację, której bohaterki całkowicie zatracają ziemską zdolność do odmierzania miesięcy, tygodni i dni. Czas, który nie upływa od jednej chwili do następnej i nie ma linearnego przebiegu, opiera się racjonalizacji i nie da się zamknąć w znajomy trójpodział przeszłość - teraźniejszość przyszłość. Formułą destabilizacji tego porządku jest retroaktywność, czyli wsteczna przyczynowość. W takim postrzeganiu wydarzeń, zgodnie $\mathrm{z}$ formułą post hoc ergo propter hoc (po tym, a więc dlatego), zdarzenie B następujące po zdarzeniu A było jednocześnie jego przyczyną. Ta paradoksalna przyczynowość czyni z łańcucha wydarzeń koło lub pętlę, w której nie ma ani początku, ani zakończenia. Choć takie rozwiązanie nie jest dla kina żadnym novum, to właśnie w „kobiecym” science fiction 

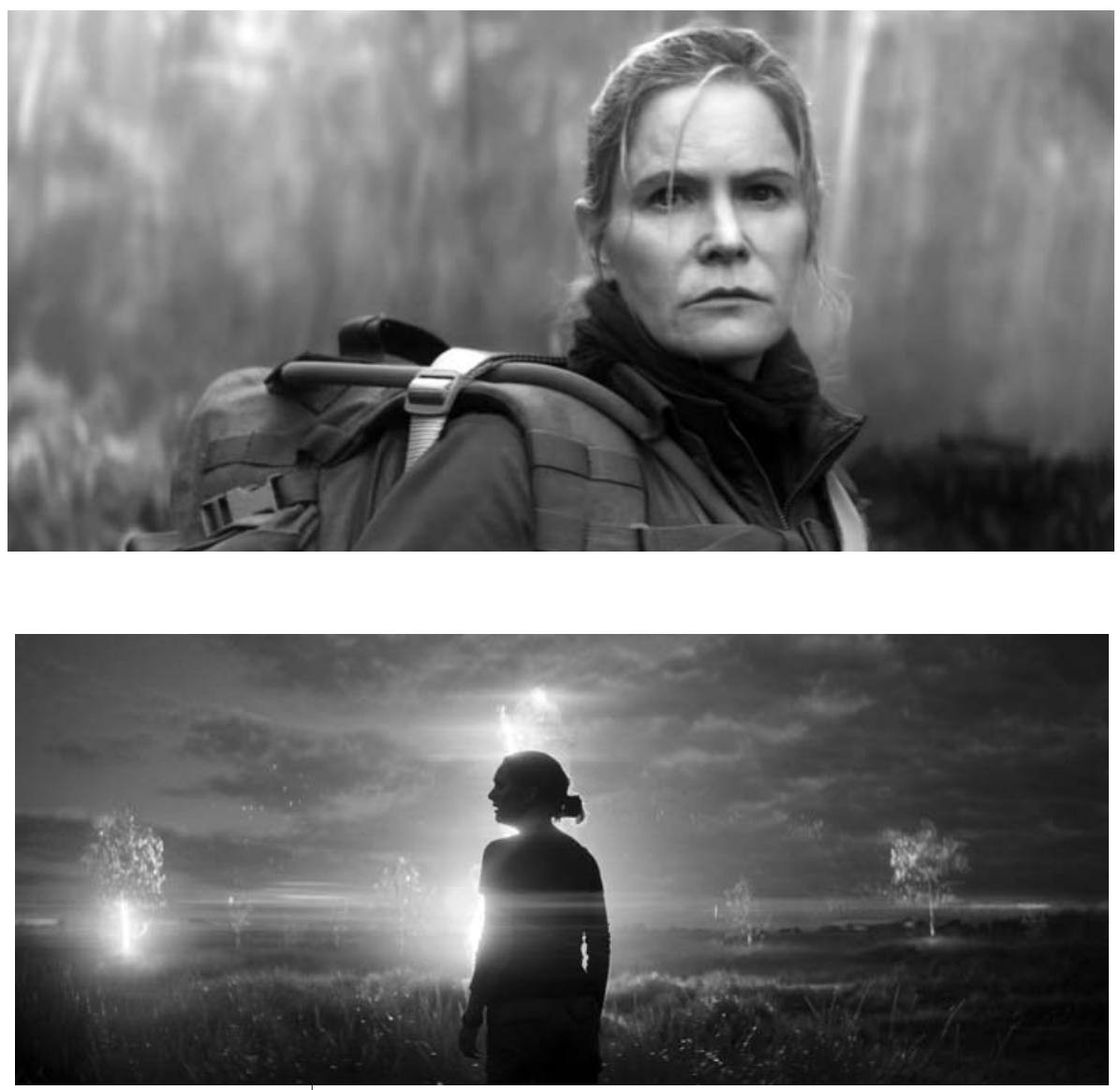

Anihilacja, reż. Alex Garland (2018)

zyskuje status tematu i ostatecznego przeżycia, będącego kolejnym wariantem doświadczania obcości.

W Nowym poczatku Denisa Villeneuve'a ${ }^{17}$ kolistość czasu zostaje przedstawiona w dwóch wymiarach: w czasie monumentalnym i mikroczasie ${ }^{18}$. Pierwszy odnosi się do tego, co „kosmiczne” i strukturowane ponadindywidualnie, dotyczy temporalnej organizacji wszechświata. Drugi to codzienność bohaterki związana z jej macierzyństwem i traumą po śmierci córki. To, co przygodne (zabawy z dzieckiem, odrabianie lekcji), zostaje zestrojone z uniwersalnym i kosmicznym i urasta do rangi prawideł rządzących wszechświatem. W chwili lądowania obcych na Ziemi Louise jest cenioną językoznawczynią. Zostaje poproszona przez armię amerykańską o nawiązanie kontaktu z przybyszami i zdeszyfrowanie ich języka, a co za tym idzie - ustalenie celu wizyty. Szybko okazuje się, że system językowy obcych nie jest podobny do żadnego z ziemskich kodów werbalnych. Komunikują się oni za pomocą specyficznego, niefonetycznego „pisma” - okręgów (ekwiwalentów zdań i fraz), których znaczenia modyfikują zgrubienia i wypustki. Kolistość pisma okaże się analogonem postrzegania czasu przez Heptapodów (Siedmiosto- 
powców). Ani w ich języku, ani w porządku temporalnym nie ma wyraźnego podziału na początek, środek i koniec - wszystkie te elementy cyrkulują i wpływają na siebie nawzajem. Doznanie czasu, którego nie można zmierzyć ani chronologicznie wyprostować, będzie siłą rzeczy afektywne: momentalne, intuicyjne, czasem wręcz drażniące nieprzewidywalnością. Louise jest w tej alternatywnej czasowości zapętlona podwójnie, jako językoznawczyni, która musi ocalić świat przez wyjście poza znaną strukturę myślenia oraz jako kobieta, do której docierają cokolwiek niepokojące reminiscencje: śmierć i choroba córki, której Louise nigdy nie miała. Tego typu afektywność zostaje także wpisana w doświadczanie filmu przez widzów - wizje z tragicznej przyszłości bohaterki, których ona sama nie potrafi zidentyfikować, zostają przedstawione niczym retrospekcje. Zapętlenie wspomnień, które jeszcze się nie wydarzyły i planowanie przyszłości, która już się dokonała, może przywodzić na myśl figurę uroborosa, a narracyjne uniezwyklenie zachęca do ucieleśnienia filmowej melancholii. Kolistość czasu ma bowiem mroczną stronę: nie pozwala na przepracowanie przeszłości i odżałowanie straty.

Afekt nie jest w Nowym początku związany jedynie z melodramatycznym cierpieniem. To droga poznania wszelkiej obcości: nowego wymiaru czasu, zupełnie innego języka oraz próby rozwiązania konfliktu między ziemskimi mocarstwami, które chcą zaatakować obcych. Wyraźnym motywem dźwiękowym w filmie jest przyśpieszony oddech i szybkie bicie serca, które słyszymy, gdy zdezorientowana bohaterka stara się rozwiązać piętrzące się przed nią problemy. Najczęściej staje przed czymś „niesamowitym” - nowym językiem, niepojętymi nie-ludźmi, zagmatwanym porządkiem wydarzeń. Afekt jest tu zarówno przedjęzykowy, jak i a-racjonalny. Zanim Louise zdekoduje język Heptapodów, nawiąże z nimi bezsłowny kontakt innego rodzaju: oparty na intuicyjnym zaufaniu, drżącej obecności, gestach empatii i próbach dotyku. Bohaterka porozumiewa się z obcymi na długo przed tym, zanim ich rozumie. Co więcej, każde jej działanie jest „działaniem w afekcie" - Louise ufa swoim instynktom, choć ich nie racjonalizuje, raczej przeczuwając niż kalkulując zasadność momentalnie podejmowanych decyzji.

Na tego typu afektywnej i pozajęzykowej komunikacji - odczuciu i intuicji przekraczających czas i przestrzeń - opiera się inny melodramat fantastycznonaukowy - Interstellar. Indywidualność codziennych doświadczeń okazuje się tu równie istotna, jak niepojęte prawidła rządzące kosmosem.

\section{Przyziemność - nieważkość}

Można odnieść wrażenie, że kino opowiadające o kosmosie jeszcze nigdy nie było tak bardzo przyziemne. W filmie Christophera Nolana widowiskowe sekwencje podróży międzygwiezdnych mają swoją kulminację w pokoiku córki głównego bohatera, Murph (Jessica Chastain). Opowieść zatacza koło tuż obok regału z książkami, zza którego pozostający w piątym wymiarze ojciec (Matthew McConaughey) da swej córce, przyszłej naukowczyni, wskazówkę, jak uratować ludzkość. Ponownie mamy do czynienia z retroaktywnością - coś, co wydarza się w niezidentyfikowanej przyszłości, wpływa na przeszłość w taki sposób, by przyszłość mogła się wypełnić. Znowu - jak w Nowym początku - losy świata zależą od intymnej więzi między najbliższymi osobami przekraczającej granice czasu i przestrzeni. W centrum tej fantastycznonaukowej melodramatyczności lokują się 
nie tylko afekty, lecz także emocje - miłość oraz poczucie silnej, choć opierającej się racjonalizacji więzi z bliskimi. Podobnie jak w strukturze narracyjnej właściwej melodramatowi ${ }^{19}$ oraz $\mathrm{w}$ trybie dyskursu popkulturowego, który Peter Brooks nazwał wyobraźnia melodramatyczną ${ }^{20}$, racja moralna zostaje przyznana bohaterce kierującej się emocjami i uczuciami. Co więcej, emocje wcale nie są przeciwieństwem nauki i logicznego rozumowania, lecz dopełniają je bądź wręcz są ich podstawą wynikają wszakże z zaangażowania i gotowości. Bohaterki Nowego początku, Interstellar, Devs, Star Trek: Discovery i Anihilacji w swych poczynaniach kierują się nie tylko wiedzą i doświadczeniem naukowym, ale też swoistą „etyką afektywną” - nie trywializują intuicji i odczuć jako typowo kobiecych skaz, lecz czynią z nich barometr, który zarówno kierunkuje ich sukces naukowy, jak również pozwala podejmować słuszne i empatyczne decyzje. Owa racja moralna bohaterek ma drugie melodramatyczne źródło - legitymizuje ją cierpienie. Jak zauważa Augustin Zarzosa, królestwo melodramatu nie jest światem zamieszkanym przez rzeczy, których istota nam ucieka; to świat, w którym wartości powoduja cierpienie, a epistemologiczna misja nie jest poszukiwanie idei, która mogłaby ujawnić istotę rzeczy, ale takiej, która mógłby owo cierpienie zatrzeć lub przynajmniej nadać mu sens ${ }^{21}$. Trauma po faktycznej utracie bliskich lub widmo ostatecznej rozłąki dotyka wszystkie bohaterki opisywanych tu filmów. Ten gatunkowy mezalians, jak by go zapewne widzieli elitaryści, Mark Fischer opisał jako eerie love - „przedziwną miłość” mediującą indywidualną emocjonalność i kosmiczną tajemnicę. Miłość nie z tej ziemi przesuwa się ze strony pozornie oswojonego na stronę nieznanego ${ }^{22}$, będąc immanentną częścią prawideł wszechświata, których ogrom zdaje się poza ludzkim pojęciem - choć nie odczuciem.

Oprócz takiego rodzaju uczuciowości kino science fiction eksploruje inne nieziemskie doznanie - stan nieważkości. Uwolnienie się od grawitacji jest kolejnym typem poczucia obcości, które może udzielić się również widzom. Choć dryfowanie w kosmosie nie jest dla kina science fiction niczym nowym i bynajmniej nie dotyczy wyłącznie postaci kobiecych, jest doświadczeniem silnie afektywnym. Współczesna fantastyka naukowa, korzystająca z arsenału technik cyfrowych, będzie się starała jak najatrakcyjniej przedstawić nieważkość - właśnie w taki sposób, by była kinową „atrakcją" - sensomotorycznym doznaniem, podatnym na ucieleśnienie przez odbiorców. Właśnie tutaj ujawnia się kreatywna i afektywna moc kina, które wprawia nas w ruch i na czas seansu oferuje "nie nasze” doznania. Ślady takiego zaafektowania są obecne w różnych dyskursach i teoriach filmowych: od fenomenologii przez koncepcje afektów po ujęcia kognitywne związane $\mathrm{z}$ ucieleśnionym umysłem ${ }^{23}$. O tym, w jaki sposób ruchome obrazy poruszają także widzów, pisał już Siegfried Krakauer: obrazy filmowe działaja w pierwszej kolejności na zmysty widza i wywotuja efekty fizjologiczne, zanim widz może zareagować intelektualnie. (...) Ruch jest alfa i omega kina. Otóż widok ruchu wywotuje prawdopodobnie „efekt rezonansu”, powodując u widza także reakcje kinestetyczne, jak odruchy mięśniowe, impulsy motoryczne i tym podobne. W każdym razie ruch obiektywny działa jako bodziec fizjologiczny ${ }^{24}$. Gilles Deleuze nie był daleki od tego spostrzeżenia: o każdej sztuce należy powiedzieć: artysta pokazuje afekty, wymyśla afekty, (...) tworzy je nie tylko $w$ swoim dziele, ale daje nam je i sprawia, że stajemy się wraz z nimi, wciaga nas $w$ to, co połaczone $e^{25}$. Doświadczanie kina dotyczy także kinetyki widzów i przejawia się w naszych reakcjach sensomotorycznych. Stan nieważkości jest dla bohaterów Grawitacji, Interstellara, Nowego początku i Ad Astra doświadczeniem zgoła intrygują- 
cym, niecodziennym i lokującym się na granicy niepokoju i przyjemności. Inność tej cielesnej kinetyki zostaje oddana za pomocą filmowych środków wyrazu, przede wszystkim różnorakich opracowań ruchu: wewnątrzkadrowego, kamery oraz trajektorii montażu. Adriano D’Aloia wskazywał, że kinodynamika filmów rozgrywających się w przestrzeni kosmicznej opiera się na motoryce filmowej, w skład której wchodzą: (1) liniowa jazda kamery (odjazd lub najazd w głąb kosmosu), (2) panorama z perspektywy bohatera, (3) obracanie kamery względem jakiegoś punktu oraz (4) powolny odjazd i najazd na bohatera ${ }^{26}$. To właśnie orkiestracja ruchów specyficznych dla tego podgatunku filmów działa na widzów afektywnie, "wprawiając” nas w stan nieważkości, symulując dryf w kosmosie i brak punktu podparcia. D'Aloia zakłada ponadto, że na najbardziej podstawowym poziomie empatii ruchy widza synchronizuja się z ruchami postaci ${ }^{27}$. Badacz skupia się na paradoksie ucieleśniania przez widzów nieważkości bohaterów filmowych, które polega na przyswajaniu nicowanego doznania czasu i przestrzeni ${ }^{28}$. "Grawitacja" - twierdzi-oznacza cezure, "punkt bez powrotu” w historii gatunku; stan zawieszenia (,suspense”) jest tu dosłownie i cieleśnie doświadczany (dzięki zmyślnemu użyciu 3D). Wszystkie rozwiązania formalne zyskuja użyteczność w przekazywaniu widzom psychofizycznej względności bohaterów. Rozwój akcji "Grawitacji” jest frustrujacy: fabuła koncentruje się na trudnościach w realizacji zadań, na braku ( $i$ utracie) punktów odniesienia oraz na ciagłym ryzyku uduszenia. Wszystkie te wyzwania fizjologiczne sa efektywnie przekazywane widzowi, który zanurza się w fikcyjnej przestrzeni, a tym samym doświadcza trudności w poruszaniu się lub oddychaniu. Bliskość fizjologicznego stanu widza i astronautki potęguje poczucie ograniczenia i frustracji spowodowanej niemożnościa petnej kontroli ruchów ${ }^{29}$. Grawitacja, która przez większość czasu przedstawiała dryfowanie astronautów bez punktu podparcia i fizycznego odniesienia, tym samym metaforyzując egzystencjalny lęk przez stanem permanentnego zawieszenia, kończy się sensomotorycznym happy endem polegającym na lądowaniu na Ziemi i przywróceniu równowagi. Kinodynamika science fiction jest zatem przyczynkiem do filmowej identyfikacji. Poza sensomotorycznym poczuciem alienacji w bezkresie kosmosu, inną - bardziej skomplikowaną i potencjalnie dyskusyjną - drogą zestrojenia widza z bohaterkami jest empatia, w której nie bez znaczenia są aspekty genderowe.

\section{Kobiecośćc - męskość}

Współczesne kino science fiction dowartościowuje kobiecą perspektywę i chętnie ogniskuje narrację wokół kobiecych doświadczeń. Dzięki takim zabiegom bohaterki są nie tylko agensami filmowego opowiadania, lecz także jego fokalizatorkami - to przez ich wiedzę, odczucia i doświadczenia poznajemy filmowy świat i rządzącą nim specyfikę. Kobieca emocjonalność, początkowo budząca sceptycyzm męskich bohaterów, okazuje się nieocenioną formą poznania.

Jak w przypadku wielu filmów, tak we współczesnym kinie fantastyczno-naukowym, granice między obiektywnością podmiotowością a subiektywnością bywają nieostre. W ich rozpoznaniu użyteczna okazuje się koncepcja fokalizacji, którą można definiować jako wybór lub ograniczenie informacji w zwiazku z doświadczeniem i wiedza narratora, postaci lub innych, bardziej hipotetycznych instancji świata opowieści $i^{30}$. Taka „manipulacja” narracją filmową stawia w jej centrum bohaterki, ale też każe wątpić w ich racjonalność. Protagonistki Anihilacji, Nowego początku, 
Interstellara czy Proximy kierują się niejasną logika, a sytuując się w kontrze do „racjonalnych" rozwiązań, są wiedzione przeczuciem i ufają własnym instynktom. Nawet gdy wątpią w siebie, narracja filmu finalnie przyznaje im rację. Jedną z bohaterek Interstellara jest naukowczyni i astronautka Amelia Brand (Anne Hathaway) - córka szefa konspiracyjnie działającej NASA. Wraz z protagonistą filmu i dwoma innymi towarzyszami wyrusza na poszukiwanie planety B, którą ludzkość mogłaby skolonizować, gdy Ziemia nie będzie już zdatna do życia. Przed tą ekspedycją na poszukiwanie ziemiopodobnych planet ruszyło troje naukowców - każde z nich miało dotrzeć do potencjalnego nowego domu ludzi i prowadzić obserwacje w celu ustalenia, czy dane miejsce można zamieszkać. Bohaterowie Interstellara odwiedzają najpierw planetę, z której szybko muszą się ewakuować. Stają przed wyborem, na którą wybrać się następnie. W grę wchodzi planeta doktora Manna (Matt Damon) oraz doktora Edmunda - który, jak się okazuje, jest ukochanym Amelii. Kobieta podejmuje podwójnie trudną decyzję - nie tylko racjonalnie szacuje dane, lecz także musi wydestylować swój osąd z jakichkolwiek sentymentów. Zdaje się, że mimo wiedzy i intuicji poniekąd sama się cenzuruje, by nie być posądzona o działanie w afekcie. W końcu, motywowana - jak się wydaje - obiektywizmem i pragmatyzmem, wybiera misję na planetę doktora Manna. Jak okazuje się w finale filmu, była to decyzja błędna - najlepsze warunki dla ludzkości panowały właśnie tam, gdzie wyruszył Edmund, który nie dożył spotkania $\mathrm{z}$ ukochaną.

Dylematy Amelii Brand podzielają niemal wszystkie bohaterki opisywanych filmów. Każda z nich, mimo znakomitego przygotowania, niekwestionowanej i instytucjonalnie legitymowanej wiedzy oraz doświadczenia zawodowego, walczy z odium „irracjonalności” stereotypowo przypisywanej kobietom. Protagonistki współczesnego science fiction nieustannie trzymają gardę przed oskarżeniami o emocjonalność, nierzadko - nie potrafiąc do końca wyzbyć się zinterioryzowanego seksizmu - podejrzewają swój rozsądek o zainfekowanie nadmierną uczuciowością. Tak jest w przypadku Lily, bohaterki Devs, która od początku podejrzewa, że śmierć jej narzeczonego na terenie wielkiego parku technologicznego nie była samobójstwem, lecz starannie zaplanowanym morderstwem. Bohaterka w niezwykle przewrotny sposób wykorzystuje odwieczną broń mężczyzn - strategię gaslightingu. Przekonuje oprawców ukochanego, że udało im się wmanewrować ją w zdiagnozowaną chorobę psychiczna, tymczasem to ona manipulowała swoim zachowaniem tak, że technokraci uwierzyli w efektywność swych wyrachowanych działań. W końcu, dzięki wiedzy wzmocnionej przeczuciem i afektem, udaje jej się nie tylko rozwikłać zagadkę morderstwa, lecz także odegrać kluczową rolę w serialowej opowieści. Podobnie postępuje Maeve, androidka i pracownica seksualna z Westworld. Jej zadaniem jej zaspokajanie potrzeb klientów parku rozrywki będącego symulakrum Dzikiego Zachodu. Po odegraniu przypisanej jej roli, zaprojektowanej przez włodarzy parku, jej pamięć zostaje zresetowana - Maeve przeżywa takie „restarty” wielokrotnie. Jako pracownica saloonu jest wystawiana na upokorzenia i przemoc: seksualną, fizyczną i psychiczną. Jednak podczas kolejnego resetu bohaterka zaczyna czuć się nieswojo, uderzają w nią odłamki trudnych do ulokowania wspomnień. Owa dziwność ma naturę afektywną - jest trudna do nazwania czy opisania, niemniej motywuje bohaterkę do działania i dojścia do prawdy. Kolejnym śladem jest nabój, który kobieta wy- 
ciąga z ciała - niechciana pamiątka po poprzednim „„życiu”. Ciało i afekt stają się zatem nie tylko drogą do prawdy, ale także zaczynem samoświadomości, która nadaje historiom z Westworld nowy bieg.

Powyższe przykłady pokazują że współczesne kino science fiction docenia kobiecą podmiotowość. Nie bez znaczenia jest sposób, w jaki to robi. Wspomniany wcześniej zabieg fokalizacji sprawia, że o filmowych i serialowych światach często wiemy tyle, ile zamieszkujące je bohaterki. To za pośrednictwem ich struktur poznawczych i uczuciowości poznajemy rzeczywistość, podobnie się w niej gubiąc. Nieprzejrzysta struktura opowiadania filmowego (ochoczo korzystająca z ekstatycznej narracji właściwej mind-game films) mediuje trudności w oswojeniu świata, który rządzi się odmiennymi regułami temporalnymi. Zabieg ten umożliwia widzom nie tylko obserwację zachowania bohaterek, lecz także jego ucieleśnienie zaabsorbowanie doświadczania obcości, przyszłości czy czasu. Takie przedstawienie subiektywności, doznaniowości lub emocjonalności warunkuje także kinową empatię. Afekty - jak pisze Anna Burzyńska - wpływają na nasze emocjonalne relacje z innymi ludźmi; empatię jaka wobec nich odczuwamy; nieuchwytne odczucia przeptywajace między ciałami, zwiazane z ich usytuowaniem w przestrzeni i podlegajace stałemu negocjowaniu $^{31}$. Ten afektywny komponent uzupełnia koncepcję science fiction jako poznawczego uniezwyklenia autorstwa Darko Suvina. Współczesna „kobieca” fantastyka naukowa nie tylko rozszerza granice naszego poznania, lecz także odczuwania - jest również uniezwykleniem afektywnym. Zachęca do doznawania innych modeli czasu (Nowy początek), łączenia wiedzy i intuicji (Devs, Westworld), otwartości na obcość (Anihilacja), dowartościowania prywatności i osobistych historii (Interstellar). Kobiecość jest tu wartością autonomiczna, a nie „mutacją” czy wariantem normatywnej męskości. Ta z kolei zostaje poddana nieuniknionym przemianom.

Współczesne kino odzyskuje afekt w świecie zdominowanym przez technologię sprzężoną z kapitalizmem. Nie dziwi zatem, że „zaafektowane” kobiece bohaterki często muszą stawić czoło męskim technokratom - toksycznym patriarchom, których niezaspokojona potrzeba samorealizacji skrywa kompleks boga z technologicznymi atrybutami wszechwiedzy, wszechwładzy i wszechmocy. Oscar Isaac w Ex Machina, Anthony Hopkins w Westworld i Nick Offerman w Devs są waloryzowani negatywnie jako żądni władzy i doskonałości. Ten ostatni został też naznaczony rysą fantastycznonaukowego melodramatyzmu - ambitny plan stworzenia symulakrum doskonałego, w którym mógłby odtworzyć szczęśliwe życie z żoną i córka, wyrósł z poczucia winy za wypadek samochodowy, w którym zginęły. Melodramat ojcowski jest trybem narracji w Pierwszym człowieku i w Ad Astra, a także w Interstellar, którego główny bohater doświadcza okrutniej ironii względności czasoprzestrzennej, spotykając swoją córeczkę dopiero jako stulatkę na łożu śmierci. Bohaterowie grani przez Brada Pitta i Ryana Goslinga nie potrafią znaleźć miejsca w kosmosie, najpierw muszą zidentyfikować skomplikowane relacje z najbliższymi. Jeśli zatem traktować kino science fiction jako kino futurystyczne, okaże się, że przyszłość wiąże się nie tyle z tak zwanym kryzysem męskości, ile z jej redefinicją zakładającą istnienie nowej męskiej modalności uczuciowo-afektywnej. 


\section{Teraźniejszość - przyszłość}

Co przyniesie przyszłość? I w jaki sposób filmowa afektywność może pomóc w próbie jej nakreślenia? Jak piszą Thomas Elsaesser i Malte Hagener, filmy nie sa jedynie obiektywnymi przedmiotami, których recepcja trwa przez ograniczony czas i które po chwili "znikaja”. Trwaja one raczej w nas, moga nas prześladować i ksztattować tak samo jak wspomnienia czy aktualne doświadczenia. Nie znajduja się ani w pełni "na zewnątrz", ani w umyśle widza; sa raczej wplecione między czas, świadomość i osobowośćc ${ }^{32}$. Choć siła rezonansu opisywanych wyżej filmów jest rzecz jasna kwestią indywidualną (w tym przypadku zapewne zależną także od płci), przedstawiona w nich obcość doświadczana, odczuwana, poznawana, będąca czasem, przestrzenią, innymi i nami samymi - ukierunkowuje nasze myśli ku przyszłości. Analizowanie fantastycznonaukowych narracji o kobietach z perspektywy afektu i doświadczenia powinno zatem odnieść je do naszego pozafilmowego tu i te raz, a w dalszej perspektywie - tam i potem. Jak przekonuje Mieke Bal: zamiast zajmować się tylko tym, co daje się zobaczyć na przykład na namalowanej powierzchni, analiza afektywna ustanawia zwiazek między widowiskiem a tym, co ono wywołuje w ludziach, którzy na nie patrza, a ściślej biorąc, sa przez nie afektywnie poruszeni ${ }^{33}$. W pewnych przypadkach - pisze dalej badaczka - obrazy nas niepokoją. Chcemy na nie oddziaływać zrobić coś ze stanem świata, którego jesteśmy świadkami. Między percepcja, która nas kłopocze, a działaniem, nad którym się wahamy, wyłania się afekt. Afekt jest okrzepła czasowościa i jednocześnie burzliwa relacje pomiędzy percepcja a działaniem, które zbiega się z podmiotowością. Innymi słowy, widz widzi (to, co jest wewnatrz ramy) $i$ waha się, co $z$ tym zrobić; jest w ten sposób pochwycony w afekt ${ }^{34}$.

Wydaje się, że ta niepewność, chęć „zrobienia czegoś ze stanem świata” oraz asymetria między percepcją i działaniem charakteryzują współczesne doświadczenia. Widmo klęski antropocenu, schyłkowość demokracji liberalnych, niewydolność późnego kapitalizmu, katastrofa ekologiczna, niepokoje społeczne i trudna do okiełznania pandemia budzą niepokój i domagają się konkretnego działania. Choć jesteśmy nimi zaafektowani, nie do końca wiemy jeszcze, co dokładnie powinniśmy robić; na domiar złego, nie jesteśmy pewni, czy nasze przedsięwzięcia nie okażą się płonne. Nie mogę się oprzeć wrażeniu, że ten egzystencjalny impas współczesnego społeczeństwa personifikują Louise z Nowego początku i Murph z Interstellar, które także nie znają odpowiedzi na wyzwania obcości. Co ciekawe, w obu filmach wskazówki dotyczące działania pochodzą od samych ludzi. Interstellar, pisał Mark Fischer, opiera się na opatrznościowej interwencji grupy rzekomych pomocnych istot - określanych jako "Oni" - które zdają się pomagać ludzkości w ucieczce z obumierajacej planety. Początkowo "Oni” tworza tunel czasoprzestrzenny, który umożliwia podróż do innej galaktyki. Na końcu filmu dowiadujemy się, że "Oni" wcale nie sa obcymi, a raczej ludźmi, którzy wyewoluowali, by zyskać dostęp do "piatego wymiaru", który pozwala im na przekroczenie czwartego - czasu ${ }^{35}$. Także w Nowym początku bohaterka poszukująca odpowiedzi na naukowe zagadnienia musi „powrócić” do własnej przyszłości.

Owa retroaktywność zdaje się przewrotnie optymistyczna. Przekonujemy się, że ocalenie ludzkości nie może przyjść z jakiegoś fantastycznego "zewnątrz" - musi wypływać z nas. By jednak jakakolwiek strategia okazała się skuteczna, 
musimy na „nas z teraz” spojrzeć z perspektywy „nas z przyszłości” (niczym bohaterowie filmu Tenet /2020/ Christophera Nolana), troszcząc się o kolejne pokolenia i przewidując wydarzenia wykraczające poza jednostkową perspektywę. Rola kobiet w tym procesie już wydaje się istotna zarówno w kinie, jak i w życiu społecznym. Perspektywiczność dziewczynek i młodych dorosłych przekłada się na odwagę działania nie tylko w filmach (Interstellar, Proxima, zakończenie High Life), lecz także we współczesnych ruchach ekologicznych. „Ekofeministyczny" szacunek dla inności i obcości, stroniący od zawłaszczania czy kolonizowania, to nie tylko domena sfeminizowanego science fiction, lecz także coraz powszechniejsza koncepcja koegzystowania w świecie pełnym różnic (nie brakuje wszakże głosów, że z zarządzaniem pandemią koronawirusa najlepiej radzą sobie kraje rządzone przez kobiety, w których polityka empatii społecznej okazała się ważniejsza niż wskaźniki ekonomii neoliberalnej). Zaafektowane i rezonujące niepewnością oczekujemy przyszłości. Ta zaś drga w szczelinie między anihilacją a nowym początkiem.

${ }^{1}$ Przymiotnik ,zaafektowany” nie występuje we współczesnej polszczyźnie, wydaje się jednak użyteczny w kontekście problematyki tekstu. Wskazuje bowiem na pobudzenie i znajdowanie się pod wpływem afektów, a tym samym na stan gotowości, w który weszliśmy dzięki nim (Wydaje się, że w taki sposób funkcjonuje podtytuł 144 numeru czasopisma „Teksty Drugie” z 2013 r. - Zaafektowani). Z kolei czasownik ,afektować" nasuwa leksykalne skojarzenie z czasownikiem ",anektować" - afekty wszakże zagarniają nas, pochłaniają i kierują (choćby chwilowo) naszymi działaniami. W obliczu werbalnego niedosytu, z którym nierzadko zmagają się badaczki i badacze piszący o afektach, będę używać obu słów w nakreślonych znaczeniach.

2 Zjawiska afektywności, melodramatyzacji i feminizacji kinowego science fiction sygnalizowałam i pokrótce opisałam w popularnonaukowym tekście Przyszłość jest kobieta? („Ekrany” 2020, nr 3, s. 26-29), w którym charakteryzuję wizerunki kobiet $\mathrm{w}$ filmowej fantastyce naukowej.

${ }^{3}$ Inaczej dzieje się w opisanym przez Andrzeja Gryza „kinie Trzeciej Kultury” - grupie (często niezależnych lub niskobudżetowych) filmów science fiction popularyzujących dokonania współczesnej nauki. Zob. A. Gryz, Kino Trzeciej Kultury. Nowe inspiracje współczesnego amerykańskiego science fiction, „Kwartalnik Filmowy” 2016, nr 93-94, s. 100-113 .

${ }^{4}$ D. Suvin, O poetyce gatunku science fiction, tłum. K. M. Maj, "Creatio Fantastica” 2018, nr 2, s. 14.
5 W. Szkłowski, Sztuka jako chwyt, tłum. R. Łużny, w: Teoria badań literackich za granica. Antologia, t. 2: Od przełomu antypozytywistycznego do roku 1945, cz. 3: Od formalizmu do strukturalizmu, wyb. S. Skwarczyńska, Wydawnictwo Literackie, Kraków 1986, s. 17. ${ }^{6}$ D. Suvin, dz. cyt., s. 21-22.

${ }^{7}$ R. Calvin, Feminist Science Fiction and Feminist Epistemology: Four Modes, Palgrave Macmillan, London 2016, s. 38.

8 Tamże, s. 31.

${ }^{9}$ S. Hven, Cinema and Narrative Complexity: Embodying the Fabula, Amsterdam University Press, Amsterdam 2017, s. 9.

${ }_{10} \mathrm{~W}$ koncepcji Moniki Fludernik doświadczeniowość to quasi-naśladowcze wywołanie prawdziwie życiowego doświadczenia, które jest właściwością fikcjonalnych narracji. Narracyjna doświadczeniowość jest mimetyczna, to znaczy odwołuje się do naszych „rzeczywistych" przeżyć, dzięki czemu jest możliwa do rozpoznania, przyswojenia i interpretacji. Zob. M. Fludernik, Towards a "Natural" Narratology, Routledge, London 1996, s. 12.

${ }^{11}$ B. Massumi, Autonomia afektu, tłum. A. Lipszyc, „Teksty Drugie” 2013, nr 144, s. 113-114 .

${ }^{12} \mathrm{~K}$. Bojarska, Poczuć myślenie: afektywne procedury historii i krytyki (dziś), „Teksty Drugie” 2013, nr 144, s. 11.

13 K. Siewior, Afekt/emocje, w: Nie-miejsca pamięci. Elementarz, red. R. Sendyka, Ośrodek Badań nad Kulturami Pamięci, Kraków 2017, s. 39.

${ }^{14}$ G. Deleuze, F. Guattari, Percept, afekt i pojęcie, $\mathrm{w}$ : tychże, Co to jest filozofia?, tłum. 
P. Pieniążek, słowo/obraz terytoria, Gdańsk 2000, s. 196.

15 Tamże, s. 191.

${ }^{16}$ L. Williams, Film Bodies: Gender, Genre, and Excess, „Film Quarterly” 1991, nr 4, s. 2-13.

${ }^{17}$ Funkcjonalność wstecznej przyczynowości Nowego początku opisałam szerzej w książce Mind-game films. Gry z narracja i widzem (Narodowe Centrum Kultury Filmowej, Łódź 2018) w podrozdziale Kolizja czasu: w petti retroaktywności (s. 84-97).

${ }^{18}$ M. Bal, Narratologia. Wprowadzenie do teorii narracji, tłum. zbiorowe, Wydawnictwo Uniwersytetu Jagiellońskiego, Kraków 2012, s. 80.

${ }^{19}$ Zob. J. Ostaszewski, Narracja melodramatyczna, w: tegoż, Historia narracji filmowej, Universitas, Kraków 2018.

${ }^{20}$ P. Brooks, The Melodramatic Imagination: Balzac, Henry James, Melodrama, and the Mode of Excess, Columbia University Press, New York 1976.

${ }^{21}$ A. Zarzosa, Melodrama and the Modes of the World, „Discourse” 2010, t. 32, nr 2, s. 242$-243$.

${ }^{22}$ M. Fisher, The Weird and the Eerie, Repeater Books, London 2016, s. 121.

${ }^{23}$ Zob. E. Twaroch-Raś, Ucieleśnienie, narracyjne wchłonięcie, afektywność $i$ "neurofilmowośćc". Perspektywy badań nad narracyjnościa filmu fabularnego, w: Narratologia transmedialna. Teorie, praktyki, wyzwania, red. K. Kaczmarczyk, Universitas, Kraków 2017.

${ }^{24}$ S. Kracauer, Teoria filmu. Wyzwolenie materialnej rzeczywistości, tłum. W. Wertenstein, słowo/obraz terytoria, Gdańsk 2008, s. 193.

${ }^{25}$ G. Deleuze, F. Guattari, dz. cyt., s. 194.
${ }^{26}$ A. D'Aloia, The Character's Body and the Viewer: Cinematic Empathy and Embodied Simulation in the Film Experience, w: Embodied Cognition and Cinema, red. M. Coëgnarts, P. Kravanja, Leuven University Press, Leuven 2015, s. 196.

27 Tamże, s. 188.

${ }^{28}$ D'Aloia w swych analizach nie różnicuje seansów 2D i 3D. Refleksja ta ma naturę modelową - koncentruje się na fenomenologii ucieleśnionego doświadczenia. Jego zróżnicowanie pod względem warunków sensu wymagałoby dodatkowych, zapewne empirycznych, badań.

${ }^{29}$ Tamże, s. 192.

${ }^{30}$ B. Niederhoff, Focalization, The Living Handbook of Narratology, http://wikis.sub.uni-hamburg. de/lhn/index.php/Focalization (dostęp: 12.06.2017).

${ }^{31}$ A. Burzyńska, Afekt - podejrzany i pożądany, w: Kultura afektu - afekty w kulturze. Humanistyka po zwrocie afektywnym, red. R. Nycz, A. Łebkowska, A. Dauksza, Instytut Badań Literackich PAN - Wydawnictwo, Warszawa 2015, s. 132.

${ }^{32}$ T. Elsaesser, M. Hagener, Teoria filmu. Wprowadzenie przez zmysty, tłum. K. Wojnowski, Universitas, Kraków 2015, s. 8.

${ }^{33}$ M. Bal, Afekt jako siła kulturowa, w: Historie afektywne i polityki pamięci, red. E. Wichrowska, A. Szczepan-Wojnarska, R. Sendyka, R. Nycz, Instytut Badań Literackich PAN Wydawnictwo, Warszawa 2015, s. 33.

34 Tamże, s. 36.

${ }^{35}$ M. Fischer, dz. cyt., s. 117.

\section{Barbara Szczekala}

Dr. nauk o sztuce, filmoznawczyni. Autorka książki Mindgame films. Gry z narracja i widzem (2018) wyróżnionej nagrodą Polskiego Towarzystwa Badań nad Filmem i Mediami w kategorii „najlepszy debiut”. Zastępczyni redaktora naczelnego czasopisma „Ekrany”. Interesuje się zjawiskami kina współczesnego, narracją filmową i doświadczeniem odbiorczym. 


\section{Bibliografia}

Bal, M. (2012). Narratologia. Wprowadzenie do teorii narracji (thum. zbiorowe). Kraków: Wydawnictwo Uniwersytetu Jagiellońskiego. (Publikacja oryginału: 1978).

Bal, M. (2015). Afekt jako siła kulturowa. W: E. Wichrowska, A. Szczepan-Wojnarska, R. Sendyka, R. Nycz (red.), Historie afektyzne i polityki pamięci (ss. 33-46). Warszawa: Instytut Badan'Literackich PAN - Wydawnictwo.

Bojarska, K. (2013). Poczuć myślenie: afektywne procedury historii i krytyki (dzis). Teksty Drugie 2013, 144, ss. 8-16.

Brooks, P. (1976). The Melodramatic Imagination: Balzac, Henry fames, Melodrama, and the Mode of Excess. New York: Columbia.

Burzyńska, A. (2015). Afekt - podejrzany i pożądany. W: R. Nycz, A. Łebkowska, A. Dauksza (red.), Kultura afektu - afekty w kulturze. Humanistyka po zwrocie afektywnym (ss. 115-134). Warszawa: Instytut Badań Literackich PAN - Wydawnictwo.

Calvin, R. (2016). Feminist Science Fiction and Feminist Epistemology: Four Modes, London: Palgrave Macmillan.

D'Aloia, A. (2015). The Character's Body and the Viewer: Cinematic Empathy and Embodied Simulation in the Film Experience. W: M. Coëgnarts, P. Kravanja (red.), Embodied Cognition and Cinema (ss. 187-199). Leuven: Leuven University Press.

Deleuze, G., Guattari F. (2000). Co to jest filozofia? (thum. P. Pieniążek). Gdańsk: słowo/obraz terytoria. (Publikacja oryginału: 1991).

Elsaesser, T., Hagener, M. (2015). Teoria filmu. Wprowadzenie przez zmysty (thum. K. Wojnowski). Kraków: Universitas. (Publikacja oryginału: 2007).

Fludernik, M. (1996). Towards a 'Natural' Narratology. London: Routledge.

Gryz, A. (2016). Kino Trzeciej Kultury. Nowe inspiracje współczesnego amerykańskiego science fiction. Kwartalnik Filmowy, 93-94, ss. 100-113.

Hven, S. (2017). Cinema and Narrative Complexity: Embodying the Fabula. Amsterdam: Amsterdam University Press.

Kracauer, S. (2008). Teoria filmu. Wyzwolenie materialnej rzeczyzistości (thum. W. Wertenstein). Gdańsk: słowo/obraz terytoria. (Publikacja oryginału: 1960).

Massumi, B. (2013). Autonomia afektu (thum. A. Lipszyc). Teksty Drugie, 144, ss. 111-134.

Niederhoff, B. (2011, 4 sierpnia). Focalization. The Living Handbook of Narratology. http://wikis.sub.uni-hamburg. de/lhn/index.php/Focalization

Ostaszewski, J. (2018). Historia narracji filmowej. Kraków: Universitas.

Siewior, K. (2017). Afekt/ emocje. W: R. Sendyka (red.), Nie-miejsca pamięci. Elementarz (ss. 36-38). Kraków: Ośrodek Badań nad Kulturami Pamięci.

Suvin, D. (2018). O poetyce gatunku science fiction (thum. K. M. Maj). Creatio Fantastica, 59 (2), ss. 9-24. https://doi.org/10.5281/zenodo.3311557

Szczekała, B. (2018). Mind-game films. Gry z narracja i widzem. Łódź: Narodowe Centrum Kultury Filmowej.

Szczekała, B. (2020). Przyszłość jest kobietą?. Ekrany, 55 (3), ss. 26-29.

Szkłowski, W. (1986). Sztuka jako chwyt (thum. R. Łużny). W: S. Skwarczyńska (wyb.), Teoria badań literackich za granica. Antologia, t. 2: Od przełomu antypozytywistycznego do roku 1945, cz. 3: Od formalizmu do strukturalizmu (ss. 10-28), Kraków: Wydawnictwo Literackie. 
Twardoch-Raś, E. (2017). Ucieleśnienie, narracyjne wchłonięcie, afektywność i „neurofilmowość”. Perspektywy badań nad narracyjnością filmu fabularnego. W: K. Kaczmarczyk (red.), Narratologia transmedialna. Teorie, praktyki, wyzwania (ss. 189-250). Kraków: Universitas.

Williams, L. (1991). Film Bodies: Gender, Genre, and Excess. Film Quarterly, 4, ss. 2-13. Zarzosa, A. (2010). Melodrama and the Modes of the World. Discourse, 32(2), ss. 242-243 .

\begin{tabular}{|c|c|}
\hline $\begin{array}{r}\text { Keywords: } \\
\text { affect; } \\
\text { melodrama; } \\
\text { womanhood; } \\
\text { science fiction; } \\
\text { embodiment; } \\
\text { empathy }\end{array}$ & $\begin{array}{l}\text { Abstract } \\
\text { Barbara Szczekała } \\
\text { Experiencing Estrangement. Womanhood, Affect and Me- } \\
\text { lodrama in Contemporary Science Fiction } \\
\text { The article presents an affective analysis of contemporary } \\
\text { science-fiction films, exploring the specificity of female ex- } \\
\text { perience within the phenomenon. I argue that affective and } \\
\text { emotional contact with extra-terrestrial estrangement is } \\
\text { a significant symptom of genre modification. This expe- } \\
\text { rience is also embodied by viewers. Despite the iconography } \\
\text { and attempts to popularize science specific to the genre, the } \\
\text { narration mode of Interstellar (dir. Christopher Nolan, 2014), } \\
\text { Arrival (dir. Denis Villeneuve, 2o16) and Annihilation (dir. } \\
\text { Alex Garland, 2018) is melodrama, and the characters think } \\
\text { and act not only through knowledge or reasoning, but also } \\
\text { through emotions or affects. The article analyzes the follo- } \\
\text { wing aspects of the latest science-fiction films: corporeal } \\
\text { notion of estrangement, affective feedback between the } \\
\text { known and unknown, alternative experience of time me- } \\
\text { diated by achronological narration, focalization and kino- } \\
\text { dynamics of cosmic spectacles, as well as affective audience } \\
\text { experiences: embodiment, empathy and identification. }\end{array}$ \\
\hline
\end{tabular}

